\title{
Pleurotus ostreatus and Ruscus aculeatus Extracts Cause Non-Apoptotic Jurkat Cell Death
}

\author{
Naji M Bassil \\ Biology Department, American University of Beirut \\ Bliss Street, PO Box 11-0236, Riyad El-Solh, Beirut 1107 2020, Lebanon \\ E-mail:nm.bassil@gmail.com \\ Roula Abdel-Massih \\ Department of Biology, University of Balamand \\ Deir El-Balamand, PO Box 100 Tripoli, El-Koura, Lebanon \\ E-mail: roula.abdelmassih@balamand.edu.lb \\ Nisrine El-Chami \\ Biology Department, American University of Beirut \\ Bliss Street, PO Box 11-0236, Riyad El-Solh, Beirut 1107 2020, Lebanon \\ E-mail: nisrinechami@hotmail.com

\section{Colin A Smith} \\ Biology Department, American University of Beirut \\ Bliss Street, PO Box 11-0236, Riyad El-Solh, Beirut 1107 2020, Lebanon \\ E-mail: cs10@aub.edu.lb \\ Elias Baydoun (Corresponding author) \\ Biology Department, American University of Beirut \\ Bliss Street, PO Box 11-0236, Riyad El-Solh, Beirut 1107 2020, Lebanon
}

Tel: 961-337-7899 E-mail: eliasbay@aub.edu.lb

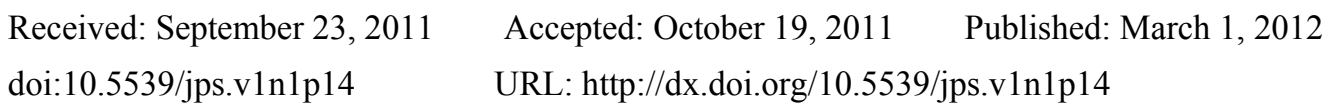

This work was supported by the National Lebanese Council for Scientific Research [Grant Number 3861/S]

\begin{abstract}
We tested the effect of ethanol extracts from Ruscus aculeatus (Asparagaceae) and Pleurotus ostreatus (Agaricales) on the survival and proliferation of the Jurkat cell line, a model of human acute T-cell lymphocytic leukemia. $R$. aculeatus extracts were toxic to both Jurkat cells and human primary lymphocytes. P. ostreatus extracts were significantly more toxic to Jurkat cells than primary lymphocytes, as seen by LDH release and MTT assays. Annexin-V detection as well as Bax, Bcl-2, Smac/Diablo, and Caspase-8 expression were largely unchanged by $P$. ostreatus extracts. Cell cycle analysis and CDK-4 expression revealed stop of Jurkat cell proliferation. Interestingly, both extracts cause a strong, dose-dependent decrease in p53 levels in Jurkat cells, consistent with toxicity and cell death occurring via an unknown, non-apoptotic mechanism.
\end{abstract}

Keywords: Acute lymphocytic leukemia, Jurkat, Pleurotus ostreatus, Ruscus aculeatus 


\section{Introduction}

Acute lymphocytic leukemia (ALL), also known as acute lymphoid leukemia or acute lymphoblastic leukemia is a cancer of the lymphocytes that appears and advances very rapidly (Weber, 2007). ALL is the most common type of childhood cancer [American Cancer Society], hence it is an attractive therapeutic target.

There is a need for complementary and alternative approaches to standard cancer therapies (Weinner, Surana \& Wang, 2010; Syljuasen \& McBride, 1999). Natural products have promising results as potential treatment for cancer in general and ALL in particular (Jadhav et al., 2007; Tai et al., 2010; Abdel-Massih et al., 2010; Davicino et al., 2010).

Ruscus aculeatus, commonly known as butcher's broom, belongs to the Asparagaceae family and is native to the Mediterranean. Extracts from this plant have been used in traditional medicine (Guarrera, 2005). Studies have shown that $R$. aculeatus extracts are active against blood disorders such as venous insufficiencies, edema, orthostatic hypotension, and inflammation (Liu et al., 2002; Huang et al., 2008; Mimaki et al., 1998). Notably, two saponin compounds found in the alcoholic extract of $R$. aculeatus inhibit the growth of the human promyelocytic leukemia cell line HL-60 (Lindequist, Niedermeyer \& Julich, 2005).

The Pleurotus genus, also known as the oyster mushroom, which belongs to the family Agaricales, is a common edible mushroom widely used in folk medicine (Jayakumar, Ramesh, \& Geraldine, 2006). Studies have shown that P. ostreatus extracts have antioxidant activity and can inhibit proliferation of human cancer cells (Jedinak \& Sliva, 2008; Venkatakrishnan et al., 2010; Wang, Gao \& Ng, 2000). A lectin extract from P. ostreatus has activity against hepatoma and sarcoma cells (Lavi et al., 2006). An aqueous polysaccharide extract induced a colon cancer cell line to undergo apoptosis (Sun \& Liu, 2009), and water-soluble polysaccharides extracted from P. ostreatus have immunomodulating and antitumor effects (Schneider, Schwenk \& Bornkamm, 1977).

The Jurkat cell line is a human acute T-cell lymphoblastic leukemia cell line used for interleukin-2 production and for testing the susceptibility of ALL to different drugs (Kendig \& Tarloff, 2007).

In light of their previous tested effects on cancer cell lines, this study tested the ethanol extracts from $R$. aculeatus and $P$. ostreatus on the survival and proliferation of the Jurkat cell line by using biochemical and molecular approaches.

\section{Material and Methods}

\subsection{Extract preparation}

The plant $R$. aculeatus was collected from northern Lebanon, washed with water and dried. The shoots were ground and soaked in $80 \%$ ethanol with shaking for 1 week. The crude extract was filtered and evaporated in a rotoevaporator at room temperature, followed by concentration in a Centrivap Concentrator (Labconco, Missouri) until it was completely dry. The resulting powder was weighed, and dissolved in RPMI 1640 media to a density of $1000 \mathrm{mg} / \mathrm{ml}$. The solution was then sterilized using a $0.45 \mu \mathrm{m}$ pore size filter, and $1 \mathrm{ml}$ aliquots were prepared and stored at $-20^{\circ} \mathrm{C}$ for later use. On the day of the experiment, the aliquots were thawed and kept on ice until used.

The mushroom $P$. ostreatus was cultivated adopting the "layer spawning" method. Freshly-harvested whole mushrooms were shade dried and finely powdered. A sample of $100 \mathrm{~g}$ of powder was extracted with $80 \%$ ethanol with shaking for 1 week. The same procedure used for $R$. aculeatus was adopted to obtain $P$. ostreatus aliquots.

\subsection{Cell culture}

Jurkat cells were suspended in RPMI 1640 medium containing $25 \quad \mathrm{mM}$ 4-[2-hydroxyethyl]-1-piperazineethanesulfonic acid (HEPES) and L-glutamine (Lonza, Belgium), supplemented with 10\% Fetal Bovine Serum (FBS) (Sigma, USA) and $100 \mathrm{U} / \mathrm{ml}$ of penicillin-streptomycin (Lonza, Belgium). The cells were grown in a humidified incubator with $5 \% \mathrm{CO}_{2}$ at $37^{\circ} \mathrm{C}$. Media was changed every second day, and the cells were passaged every four days at a ratio of $1: 4$.

\subsection{Cytotoxicity assay}

The cytotoxicity of each extract on the Jurkat cell line was assessed using the lactate dehydrogenase (LDH) Cytotoxicity Detection Kit (Takara Bio Inc., Japan.). The assay was performed according to the manufacturer's protocol. The tested conditions were $1,2,4,5,8,10,16,20,32,40$, or $60 \mathrm{mg} / \mathrm{ml}$ of extract diluted in $1 \%$ FBS containing media, at $6 \mathrm{hrs}, 24 \mathrm{hrs}$, or $48 \mathrm{hrs}$. For the $48 \mathrm{hrs}$ period, the cells were fed at the $24 \mathrm{hrs}$ time point. Each condition was done in triplicate, and the results shown represent the average of three independent experiments.

Normal lymphocytes from EDTA-anticoagulated peripheral blood of a normal human donor were isolated using the standard Ficoll-Paque Plus gradient method (GE Healthcare, USA) and subsequently washed twice in 
complete RPMI 1640 medium. Cells were suspended in complete RPMI 1640 medium, following which the same procedure for the cytotoxicity test was used.

\subsection{Metabolic activity test}

Metabolically active cells were assessed using the Cell Proliferation Kit I (MTT) (Roche Applied Sciences, Germany). The assay was performed according to the manufacturer's protocol. The tested conditions were 1, 2, 4, $5,8,10,16,20 \mathrm{mg} / \mathrm{ml}$ of extracts diluted in $10 \%$ FBS-containing media, at either 24 or $48 \mathrm{hrs}$. Cells kept past 24 hrs were fed at the $24 \mathrm{hrs} \mathrm{time} \mathrm{point.} \mathrm{Each} \mathrm{condition} \mathrm{was} \mathrm{done} \mathrm{in} \mathrm{triplicate,} \mathrm{and} \mathrm{the} \mathrm{results} \mathrm{shown} \mathrm{are} \mathrm{the} \mathrm{average} \mathrm{of}$ three independent experiments.

\subsection{Annexin V-FITC}

Cells were seeded at a density of $5 \times 10^{5}$ cells $/ \mathrm{ml}$ in a $24-$ well cell culture plate and were incubated for $24 \mathrm{hrs}$. They were treated with 8,10 , or $16 \mathrm{mg} / \mathrm{ml}$ of $P$. ostreatus extract, or 8 or $10 \mathrm{mg} / \mathrm{ml}$ of $R$. aculeatus extract and incubated for $24 \mathrm{hrs}$. Cells were then harvested at a density of $5 \times 10^{5}$ cells $/ \mathrm{ml}$ and washed twice with cold 1 XPBS. The cells were gently suspended in a solution containing $100 \mu \mathrm{l}$ of Annexin V-Fluos labeling solution (Roche Applied Sciences, Germany), $5 \mu 1$ of fluorescein isothiocyanate labeled by Annexin V-FITC and $5 \mu 1$ of propidium iodide (PI). Cells were incubated in the dark at room temperature for $15 \mathrm{~min}$ before adding $500 \mu \mathrm{l}$ Annexin V-Fluos labeling solution to each well. Cells were then subjected to flow cytometry analysis using a BD FACSCalibur flowcytometer (Becton Dickinson, USA). CellQuest ${ }^{\mathrm{TM}}$ software (Becton Dickinson, USA) was used to analyze the data. Each condition was done in duplicate, and the represented results are the average of two independent experiments.

\subsection{Cell cycle analysis}

Cells were seeded at a density of $1 \times 10^{6}$ cells/ $/ \mathrm{ml}$ in a $24-$ well cell culture plate and were incubated for $24 \mathrm{hrs}$. They were treated with 8,10 , or $16 \mathrm{mg} / \mathrm{ml}$ of $P$. ostreatus extract, or 8 or $10 \mathrm{mg} / \mathrm{ml}$ of $R$. aculeatus extract and incubated for $24 \mathrm{hrs}$. The cells were harvested at a density of $2 \times 10^{6} \mathrm{cells} / \mathrm{ml}$ and washed with cold 1 XPBS. The cells were fixed in $70 \%$ ethanol and left at $-20^{\circ} \mathrm{C}$ overnight. Cells were washed with cold 1XPBS, and then treated with RNaseA (Fermentas, Canada) for $1 \mathrm{hr} 30 \mathrm{~min}$ at $37^{\circ} \mathrm{C}$. The solution was centrifuged at $200 \mathrm{~g}$ and then washed twice with cold 1XPBS. The pellet was resuspended in 1XPBS and $67 \mu \mathrm{g} / \mathrm{ml}$ PI (Invitrogen, USA) and incubated for $10 \mathrm{~min}$ in the dark and read on a FACScan flowcytometer (Becton Dickinson, USA). CellQuest ${ }^{\mathrm{TM}}$ software (Becton Dickinson, USA) was used to analyze the data. Each condition was done in duplicate, and the represented results are the average of three independent experiments.

\subsection{Protein extraction and western blot}

Cells were seeded at a density of $1 \times 10^{6}$ cells $/ \mathrm{ml}$ in a 24 -well cell culture plate and incubated for $24 \mathrm{hrs}$. Then they were treated with $1-20 \mathrm{mg} / \mathrm{ml}$ of $P$. ostreatus or R. aculeatus extract and incubated for $24 \mathrm{hrs}$. The cells were then harvested and washed with cold 1XPBS. Proteins were extracted from cells using a lysis buffer containing $25 \mathrm{mM}$ Tris- $\mathrm{HCl} \mathrm{pH}$ 7.6, $140 \mathrm{mM} \mathrm{NaCl}, 1 \%$ TritonX-100 (w/v), 0.5\% SDS, and protease inhibitors. Lysates were left on ice for $40 \mathrm{~min}$, then centrifuged at $14,000 \mathrm{~g}$ for $10 \mathrm{~min}$ at $4^{\circ} \mathrm{C}$ and the supernatant was collected and $15 \mu \mathrm{l}$ aliquots were stored at $-20^{\circ} \mathrm{C}$ for later use. At the day of the experiment, $15 \mu \mathrm{l}$ of Laemmli Sample Buffer (Bio-Rad, USA) were added to each sample, and the tubes were put at $100^{\circ} \mathrm{C}$ for $5 \mathrm{~min}$ and were directly put on ice for $30 \mathrm{~min}$. A volume of $30 \mu \mathrm{l}$ from each sample was loaded on a $12 \%$ polyacrylamide gel and run at $120 \mathrm{~V}$ for $1 \mathrm{hr} 30 \mathrm{~min}$. The proteins were electrically transferred to a methanol-activated PVDF membrane at $100 \mathrm{~V}$ for $1 \mathrm{hr} 15 \mathrm{~min}$ on ice. The membrane was probed using antibodies against either Caspase-8 (1:500), $\beta$-actin (1:2000), p53 (1:2000), Smac/Diablo (1:4000), CDK-4 (1:500), Bax (1:1000) or Bcl-2 (1:500) (Abcam, USA). $\beta$-actin was used as a control for equal loading of protein samples. Represented results are the average of four different extractions from four independent experiments.

\subsection{Statistical analysis}

Statistical analysis was done using the Statistical Package for the Social Sciences (SPSS) (Version 16, Chicago, IL) software. Outliers were identified by plotting a box and whisker plot, and one way ANOVA (Dunnet's test) was performed to compare means of data in different experiments.

\section{Results}

\subsection{Effect on cell viability and cytotoxicity}

The LDH Cytotoxicity Detection Kit detects the leakage of the cytoplasmic enzyme LDH into the extracellular medium upon damage to the cytoplasmic membrane so it can be used as an indicator of dead cells. After $6 \mathrm{hrs}$ of $R$. aculeatus treatment, Jurkat cells did not show any significant release of LDH except at $40 \mathrm{mg} / \mathrm{ml}$ (Figure 1a). In 
contrast, treatment with P. ostreatus extract showed a gradual increase in LDH release by Jurkat cells (Figure 1b). Moreover, after 24 and $48 \mathrm{hrs}$ of treatment, both extracts showed a gradual, concentration- and time-dependent increase in $\mathrm{LDH}$ release from Jurkat cells (Figure 1). The inhibitory concentration $\left(\mathrm{IC}_{50}\right.$, concentration at which $50 \%$ of cells have released LDH) at $24 \mathrm{hrs}$ was between 10 and $16 \mathrm{mg} / \mathrm{ml}$ for $R$. aculeatus, and between 16 and 20 $\mathrm{mg} / \mathrm{ml}$ for $P$. ostreatus. The $\mathrm{IC}_{50}$ at $48 \mathrm{hrs}$ was between 8 and $10 \mathrm{mg} / \mathrm{ml}$ for both $R$. aculeatus and P. ostreatus. Normal lymphocytes were used as control cells to assess the cytotoxicity of tested extracts at 24 and $48 \mathrm{hrs}$. $R$. aculeatus showed a similar cytotoxic effect to that of Jurkat cells whereas $P$. ostreatus showed much lower cytotoxicity on primary lymphocytes (data not shown).

In contrast to the LDH Cytotoxicity Detection Kit, the Cell Proliferation Kit I (MTT) detects living cells that are metabolically active. Extract activity at concentrations below $\mathrm{IC}_{50}$ in the cytotoxicity experiment were tested at 24 and 48 hrs. $R$. aculeatus extract causes a gradual decrease in the number of metabolically active cells. This decrease is both time and concentration dependant, reaching its lowest point for both time intervals at $16 \mathrm{mg} / \mathrm{ml}$, while the $\mathrm{IC}_{50}$ is $5 \mathrm{mg} / \mathrm{ml}$ (Figure 2a). In contrast, $P$. ostreatus induced an increased metabolic activity of Jurkat cells, for both time-points, at low concentrations until $8 \mathrm{mg} / \mathrm{ml}$. While the $\mathrm{IC}_{50}$ is between $10 \mathrm{and} 16 \mathrm{mg} / \mathrm{ml}$ for the $48 \mathrm{hrs}$ time-point, it reached a plateau between 10 and $20 \mathrm{mg} / \mathrm{ml}$, without reaching the $50 \%$ mark after $24 \mathrm{hrs}$ of treatment (Figure 2b).

\subsection{Apoptosis and the cell cycle}

In order to understand how these two extracts are affecting Jurkat cells, we used the Annexin V Flow Cytometry approach. We tested the concentrations that induced a change in cell behavior in the MTT assay, while still not inducing marked cell death neither in Jurkat cells, nor in normal lymphocytes in the LDH cytotoxicity assay. Our results show a significant decrease, with respect to the negative control, in the number of $\mathrm{PI}^{-} / \mathrm{A}^{-}$cells, no significant change in the number of $\mathrm{PI}^{-} / \mathrm{A}^{+}$cells, and a significant increase in the number of $\mathrm{PI}^{+} / \mathrm{A}^{-}$and $\mathrm{PI}^{+} / \mathrm{A}^{+}$cells when treating the cells with $R$. aculeatus (Table 1 ). In contrast, there is no significant change, with respect to the negative control, in the number of cells in any combination, except in the $\mathrm{PI}^{+} / \mathrm{A}^{-}$cells when treated with $16 \mathrm{mg} / \mathrm{ml}$ of $P$. ostreatus extract (Table 1).

Flow cytometry analysis of the same concentrations and time intervals as tested in the Annexin $\mathrm{V}$ experiment reveal a significant increase in the number of Jurkat cells in the sub-G1 region and a significant reduction of cells in the G1 region when treated with R. aculeatus extract (Table 2). All P. ostreatus treatments did not show any significant change in any stage of the Jurkat cell cycle (Table 2).

\subsection{Western blot}

We next examined 2 proteins that are directly involved in apoptosis: caspase- 8 for the extrinsic pathway and $\mathrm{Smac} /$ Diablo for the intrinsic pathway. Both proteins show little change over the range of tested treatments from both extracts (Figures $3 \& 4$ ). Jurkat cell CDK-4 protein levels also show little change over the range of tested treatments from $R$. aculeatus extract (Figure 3). With P. ostreatus treatment, this same protein shows a slight gradual increase between 1 and $4 \mathrm{mg} / \mathrm{ml}$ treatment, and almost disappears between 5 and $20 \mathrm{mg} / \mathrm{ml}$, with the exception of the $8 \mathrm{mg} / \mathrm{ml}$ treatment (Figure 4). Finally we tested the anti-apoptotic protein Bcl-2, the pro-apoptotic protein Bax, and the tumor suppressor protein $\mathrm{p} 53$, all of which play a role in cell proliferation, apoptosis and cell cycle arrest. $R$. aculeatus extract causes the Bax protein to show a pattern of steady slight non-significant dose-dependent increase, while the Bcl-2 protein shows no change with increasing dose (Figure 3). With $P$. ostreatus treatment, both Bax and Bcl-2 show little variation over the range of tested concentrations (Figure 4). With both extracts the p53 protein shows a steady decrease with increasing dose, with significantly lower levels than the negative control at 10,16 and $20 \mathrm{mg} / \mathrm{ml}$ (Figures $3 \& 4$ ).

\section{Discussion}

ALL is the most common type of childhood cancer [American Cancer Society]. In our study, we used the Jurkat cell line as a model of human T-cell ALL, to study the effect of ethanol extracts from R. aculeatus and P. ostreatus on the survival and proliferation of this type of cancer.

The results of the LDH experiment indicate first, that $6 \mathrm{hrs}$ are not sufficient time for the extracts to exert their function, so we abandoned this time point in further experiments; second, they indicate that we should further investigate the $1-20 \mathrm{mg} / \mathrm{ml}$ concentrations in both extracts. They also indicate that $R$. aculeatus is not a good candidate for anticancer drug development since it showed a similar cytotoxic effect on normal human lymphocytes as that on Jurkat cells. However, because we are studying an extract that may contain many active compounds, and because it has been demonstrated that a number of molecules can interfere in the release of LDH into the cellular environment (Wang, Henning \& Heber, 2010), further studies may refute this claim. 
We tested the effect of these extracts on the metabolic activity of Jurkat cells, which is an indication of proliferating cells. The results of the MTT assay with $R$. aculeatus extract are consistent with previous results (Lindequist, Niedermeyer \& Julich, 2005). In contrast, the increase in Jurkat cells' metabolic activity when treated with low concentrations of $P$. ostreatus might indicate that some compounds in the crude extract are working to induce either an increase in the mitochondrial activity, or an increase in the number of cells (proliferation), which is in turn increasing the total metabolic activity. Other groups reported similar results, while others did not see this increase at low concentrations of treatment (Venkatakrishnan et al., 2010; Wang, Gao \& Ng, 2000). These differences are most likely due to the difference in the cell lines and the concentrations of extracts used by these groups. Furthermore, these differences may also be due to the reduced sensitivity of the MTT assay as previously reported (Chen et al., 1996).

Our flow cytometry experiments reveal that both extracts did not induce apoptosis however; at high concentrations they induce a non-apoptotic form of Jurkat cell death (Table 1), which is revealed in the significant increase in the number of cells in the sub-G1 and a decrease in the G1 regions when treated with $R$. aculeatus extract (Table 2).

The fact that neither the proteins that are directly involved in apoptosis (Caspase- 8 and Smac/Diablo), nor the ones that are indirectly involved in apoptosis (Bcl-2 and Bax), showed any significant change with increasing concentration of either extract, confirms the flow cytometry results and the claim that these extracts are not inducing apoptotic cell death. The observed result that $P$. ostreatus induces Jurkat cells to increase the expression of the CDK-4 protein, at low concentrations, may be the reason behind the increase in the MTT assay. At high concentrations this protein is inhibited which indicates, along with the insignificant change in cell cycle, a stop of proliferation and later death by a non-apoptotic process or senescence and thereby reduced metabolic activity. Finally the observed decrease in $\mathrm{p} 53$ level upon treatment with both extracts may be a result of cell cycle arrest, as suggested previously (Cheng \& Hass, 1990). It was also shown that the p53 protein is highly mutated in the Jurkat cell line with missense or nonsense mutations. These mutations render the protein inert for both inducing apoptosis and inducing cell cycle arrest (Cheng \& Hass, 1990), indicating that this down regulation effect may be a result of increased sensitivity of the cells to undergo death, instead of being a cause of cell death on its own. Taken together, these results indicate that both extracts cause non-apoptotic Jurkat cell death at high concentrations. The main difference is that $R$. aculeatus extract causes death of normal lymphocytes as well. In contrast, $P$. ostreatus extract causes stop of proliferation of Jurkat cells, and has no effect on normal lymphocytes.

\section{References}

Abdel-Massih, R. M., Fares, R., Bazzi, S., El-Chami, N., \& Baydoun, E. (2010). The apoptotic and anti-proliferative activity of Origanum majorana extracts on human leukemic cell line. Leukemia Research, 34(8), 1052-1056. http://dx.doi.org/10.1016/j.leukres.2009.09.018

Chen, X., Ko, L. J., Jayaraman, L., \& Prives, C. (1996). p53 levels, functional domains, and DNA damage determine the extent of the apoptotic response of tumor cells. Genes \& Development, 10(19), 2438-2451. http://dx.doi.org/10.1101/gad.10.19.2438

Cheng, J., \& Haas, M. (1990). Frequent mutations in the p53 tumor suppressor gene in human leukemia T-cell lines. Molecular and Cellular Biology, 10(10), 5502-5509.

Davicino, R., Manuele, M. G., Turner, S., Ferraro, G., \& Anesini, C. (2010). Antiproliferative activity of Larrea divaricata Cav. on lymphoma cell line: participation of hydrogen peroxide in its action. Cancer Investigation, 28(1), 13-22. http://dx.doi.org/10.3109/07357900902849665

Guarrera, P. M. (2005). Traditional phytotherapy in Central Italy (Marche, Abruzzo, and Latium). Fitoterapia, 76(1), 1-25. http://dx.doi.org/10.1016/j.fitote.2004.09.006

Huang, Y. L., Kou, J. P., Ma, L., Song, J. X., \& Yu, B. Y. (2008). Possible mechanism of the anti-inflammatory activity of ruscogenin: role of intercellular adhesion molecule-1 and nuclear factor-kappaB. Journal of Pharmacological Science, 108(2), 198-205. http://dx.doi.org/10.1254/jphs.08083FP

Jadhav, U., Ezhilarasan, R., Vaughn, S. F., Berhow, M. A., \& Sanjeeva, M. (2007). Iberin induces cell cycle arrest and apoptosis in human neuroblastoma cells. International Journal of Molecular Medicine, 19(3), 353-361.

Jayakumar, T., Ramesh, E., \& Geraldine, P. (2006). Antioxidant activity of the oyster mushroom, Pleurotus ostreatus, on CCl(4)-induced liver injury in rats. Food Chemistry and Toxicology, 44(12), 1989-1996. http://dx.doi.org/10.1016/j.fct.2006.06.025

Jedinak, A., \& Sliva, D. (2008). Pleurotus ostreatus inhibits proliferation of human breast and colon cancer cells 
through p53-dependent as well as p53-independent pathway. International Journal of Oncology, 33(6), 1307-1313.

Kendig, D. M., \& Tarloff, J. B. (2007). Inactivation of lactate dehydrogenase by several chemicals: implications for in vitro toxicology studies. Toxicology In Vitro, 21(1), 125-132. http://dx.doi.org/10.1016/j.tiv.2006.08.004

Lavi, I., Friesem, D., Geresh, S., Hadar, Y., \& Schwartz, B. (2006). An aqueous polysaccharide extract from the edible mushroom Pleurotus ostreatus induces anti-proliferative and pro-apoptotic effects on HT-29 colon cancer cells. Cancer Letters, 244(1), 61-70. http://dx.doi.org/10.1016/j.canlet.2005.12.007

Lindequist, U., Niedermeyer, T. H. J., \& Jülich, W. D. (2005). The Pharmacological Potential of Mushrooms. Evidence Based Complementary and Alternative Medicine, 2(3), $285-299$. http://dx.doi.org/10.1093/ecam/neh107

Liu, J., Chen, T., Yu, B., \& Xu, Q. (2002). Ruscogenin glycoside (Lm-3) isolated from Liriope muscari inhibits lymphocyte adhesion to extracellular matrix. Journal of Pharmacy and Pharmacology, 54(7), 959-965. http://dx.doi.org/10.1211/002235702760089081

Mimaki, Y., Kuroda, M., Kameyama, A., Yokosuka, A., \& Sashida, Y. (1998). Steroidal saponins from the underground parts of Ruscus aculeatus and their cytostatic activity on HL-60 cells. Phytochemistry, 48(3), 485-493. http://dx.doi.org/10.1016/S0031-9422(98)00036-3

Schneider, U., Schwenk, H. U., \& Bornkamm, G. (1977). Characterization of EBV-genome negative "null" and "T" cell lines derived from children with acute lymphoblastic leukemia and leukemic transformed non-Hodgkin lymphoma. International Journal of Cancer, 19(5), 621-626. http://dx.doi.org/10.1002/ijc.2910190505

Syljuâsen, R. G., \& McBride, W. H. (1999). Radiation-induced apoptosis and cell cycle progression in Jurkat T cells. Radiation Research, 152(3), 328-331. http://dx.doi.org/10.2307/3580333

Sun, Y., \& Liu, J. (2009). Purification, structure and immunobiological activity of a water-soluble polysaccharide from the fruiting body of Pleurotus ostreatus. Bioresource Technology, 100(2), 983-986. http://dx.doi.org/10.1016/j.biortech.2008.06.036

Tai, J., Cheung, S., Chan, E., \& Hasman, D. (2010). Inhibition of human ovarian cancer cell lines by Devil's club Oplopanax horridus. Journal of Ethnopharmacology, $127(2), \quad 478-485$. http://dx.doi.org/10.1016/j.jep.2009.10.010

Venkatakrishnan, V., Shenbhagaraman, R., Kaviyarasan, V., Gunasundari, D., Radhika, K., Dandapani, R., \& Jagadish, L. K. (2010). Antioxidant and antiproliferative effect of Pleurotus ostreatus. Journal of Physiology, 2(1), 22-28.

Wang, H., Gao, J., \& Ng, T. B. (2000). A new lectin with highly potent antihepatoma and antisarcoma activities from the oyster mushroom Pleurotus ostreatus. Biochemical and Biophysical Research Communications, 275(3), 810-816. http://dx.doi.org/10.1006/bbrc.2000.3373

Wang, P., Henning, S. M., \& Heber, D. (2010). Limitations of MTT and MTS-based assays for measurement of antiproliferative activity of green tea polyphenols. Public Library of Science One, 5(4), e10202. http://dx.doi.org/10.1371/journal.pone.0010202

Weber, G. F. (2007). Molecular Mechanisms of Cancer. USA: Springer.

Weiner, L. M., Surana, R., \& Wang, S. (2010). Monoclonal antibodies: versatile platforms for cancer immunotherapy. Nature Reviews Immunology, 10, 317-327. http://dx.doi.org/10.1038/nri2744 
Table 1 . Flow cytometry annexin $\mathrm{V}$ analysis

\begin{tabular}{|c|c|c|c|c|}
\hline & $\mathrm{PI}^{-} / \mathrm{A}^{-}(\%)$ & $\mathrm{PI}^{-} / \mathrm{A}^{+}(\%)$ & $\mathrm{PI}^{+} / \mathrm{A}^{-}(\%)$ & $\mathrm{PI}^{+} / \mathrm{A}^{+}(\%)$ \\
\hline Untreated & $85 \pm 6.6$ & $7 \pm 5$ & $0.2 \pm 0.2$ & $1 \pm 1$ \\
\hline $\mathrm{P} 8$ & $81 \pm 8.4$ & $10 \pm 6$ & $0.7 \pm 0.6$ & $2 \pm 1$ \\
\hline $\mathrm{P} 10$ & $83 \pm 7$ & $9 \pm 5$ & $0.6 \pm 0.6$ & $2 \pm 1.3$ \\
\hline $\mathrm{P} 16$ & $79 \pm 2.5$ & $9 \pm 4$ & $6 \pm 0.8^{*}$ & $2 \pm 1$ \\
\hline R8 & $73 \pm 3.8^{*}$ & $4 \pm 1.1$ & $10 \pm 1.3^{*}$ & $10 \pm 4^{*}$ \\
\hline R10 & $72 \pm 2.7^{*}$ & $4 \pm 1$ & $13 \pm 1.3^{*}$ & $9 \pm 2^{*}$ \\
\hline
\end{tabular}

P8: P. ostreatus $8 \mathrm{mg} / \mathrm{ml}, \mathrm{P} 10$ : P. ostreatus $10 \mathrm{mg} / \mathrm{ml}$, P16: P. ostreatus $16 \mathrm{mg} / \mathrm{ml}, \mathrm{R} 8:$ R. aculeatus $8 \mathrm{mg} / \mathrm{ml}, \mathrm{R} 10$ : R. aculeatus $10 \mathrm{mg} / \mathrm{ml}$.

Each value is the mean \pm SEM of two separate experiments done in duplicate.

* Statistically significant values with a p value of 0.05 with respect to the untreated samples.

Table 2. Flow cytometry cell cycle analysis

\begin{tabular}{|c|c|c|c|c|}
\hline & Sub-G1 & G1 (\%) & S (\%) & G2/M \\
\hline Untreated & $11 \pm 1.9$ & $44 \pm 2$ & $22 \pm 4$ & $11 \pm 3.5$ \\
\hline P8 & $13 \pm 1.3$ & $44 \pm 3.5$ & $20 \pm 3.5$ & $7 \pm 1.5$ \\
\hline P10 & $14 \pm 1.4$ & $42 \pm 3.3$ & $19 \pm 3.3$ & $9 \pm 2.8$ \\
\hline P16 & $17 \pm 0.9$ & $40 \pm 3$ & $20 \pm 3.6$ & $10 \pm 3$ \\
\hline R8 & $24 \pm 3.6^{*}$ & $31 \pm 2^{*}$ & $26 \pm 4.5$ & $11 \pm 5$ \\
\hline R10 & $27 \pm 2.7^{*}$ & $30 \pm 2^{*}$ & $25 \pm 4$ & $10 \pm 4$ \\
\hline
\end{tabular}

P8: P. ostreatus $8 \mathrm{mg} / \mathrm{ml}$, P10: P. ostreatus $10 \mathrm{mg} / \mathrm{ml}$, P16: P. ostreatus $16 \mathrm{mg} / \mathrm{ml}, \mathrm{R} 8$ : R. aculeatus $8 \mathrm{mg} / \mathrm{ml}, \mathrm{R} 10$ : R. aculeatus $10 \mathrm{mg} / \mathrm{ml}$.

Each value is the mean $\pm \mathrm{SEM}$ of three separate experiments done in duplicate.

* Statistically significant values with a p value of 0.05 with respect to the untreated samples. 

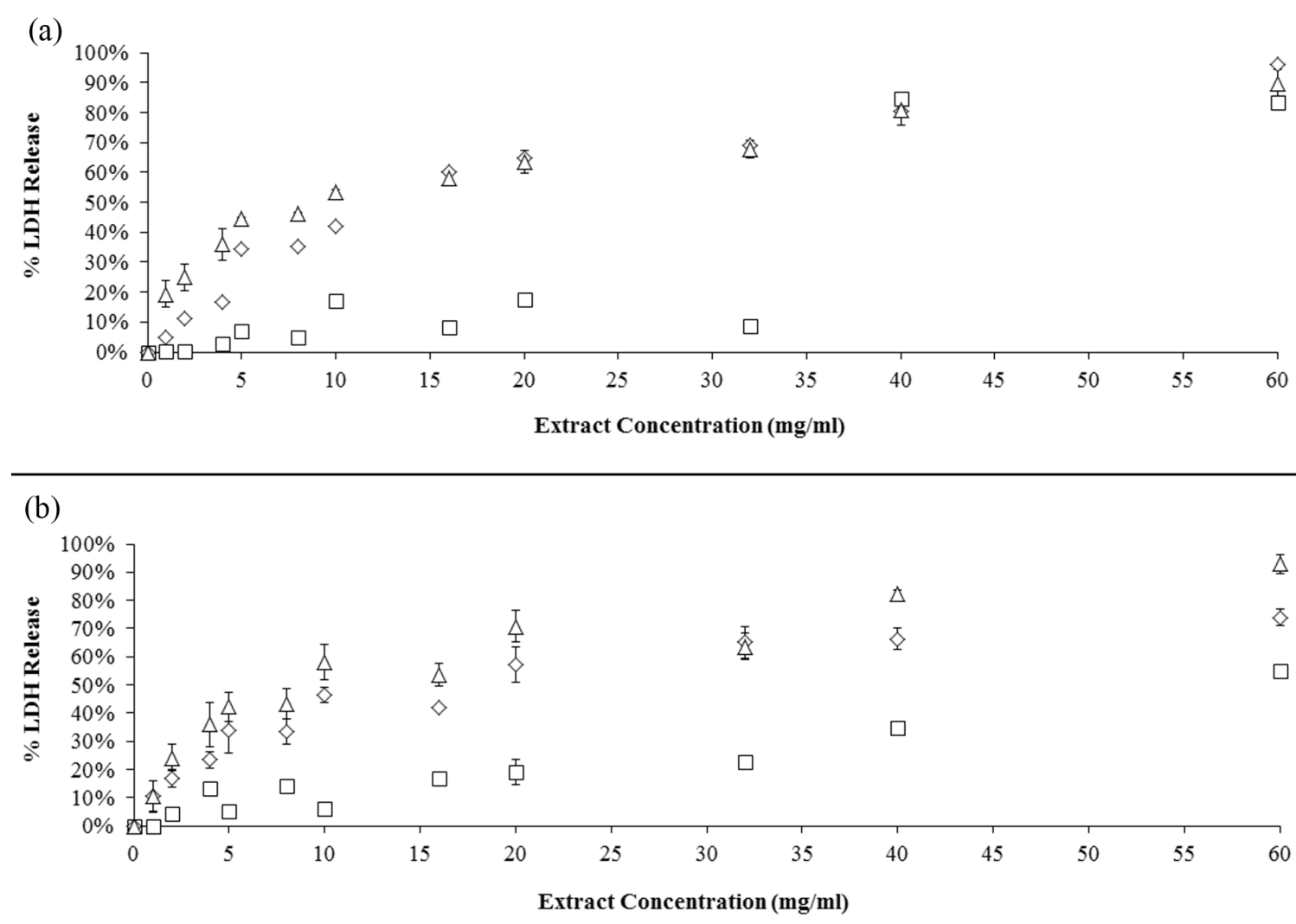

Figure 1. LDH release from Jurkat cells

LDH release from Jurkat cells after treatment with different concentrations of $R$. aculeatus (a), and P. ostreatus (b) at different time points. Error bars represent standard error of the mean of three independent experiments. 6 hrs, - 24 hrs, $\Delta$ 48hrs. 
(a)

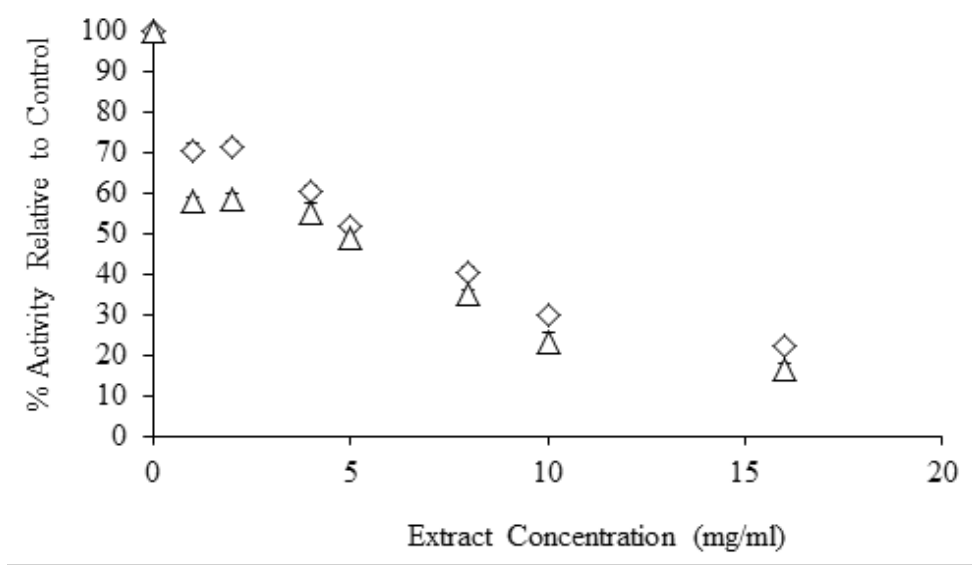

(b)

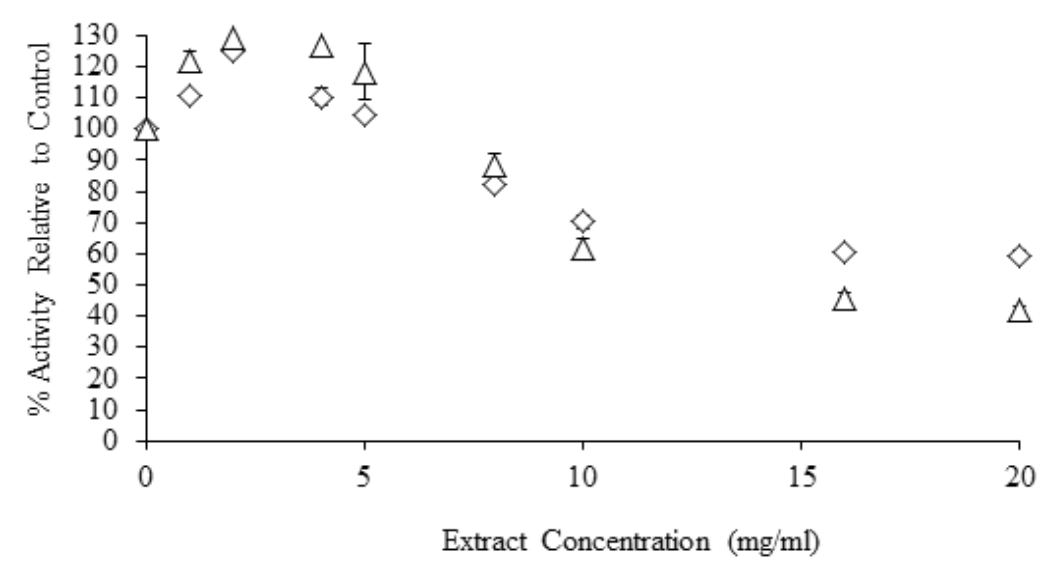

Figure 2. MTT assay for the detection of metabolically active Jurkat cells

MTT assay for the detection of metabolically active Jurkat cells after treatment with different concentrations of $R$. aculeatus (a), and P. ostreatus (b) at different time points. Error bars represent standard error of the mean of three independent experiments. $24 \mathrm{hrs}, \boldsymbol{\Delta} 48 \mathrm{hrs}$. The results of these experiments are represented as percent of cell metabolic activity relative to the untreated control. 


\section{Concentration $(\mathrm{mg} / \mathrm{ml})$}

12

45

8

10

16

20

0

Caspase-8

\section{Smac/Diablo}

\section{CDK-4}

Bax

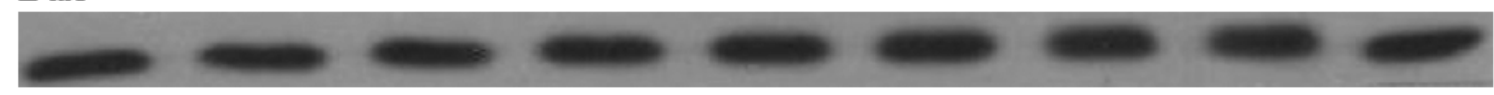

\section{Bcl-2}

P53

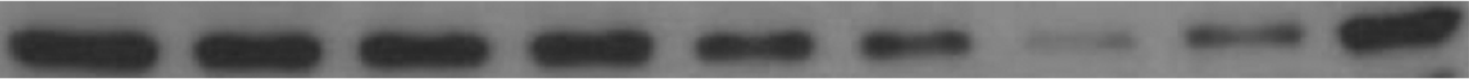

Actin

Actin

Figure 3. Western blot results for Jurkat cells treated with different concentrations of $R$. aculeatus extract

Lane 1: $1 \mathrm{mg} / \mathrm{ml}$, Lane 2: $2 \mathrm{mg} / \mathrm{ml}$, Lane 3: $4 \mathrm{mg} / \mathrm{ml}$, Lane 4: $5 \mathrm{mg} / \mathrm{ml}$, Lane $5: 8 \mathrm{mg} / \mathrm{ml}$, Lane 6: $10 \mathrm{mg} / \mathrm{ml}$, Lane 7: $16 \mathrm{mg} / \mathrm{ml}$, Lane $8: 20 \mathrm{mg} / \mathrm{ml}$, and Lane 9: the negative control which contains extracted proteins from untreated cells. 


\section{Concentration $(\mathrm{mg} / \mathrm{ml})$ \\ 12 \\ 45 \\ 8 \\ 10 \\ 16 \\ 20 \\ 0}

Caspase-8

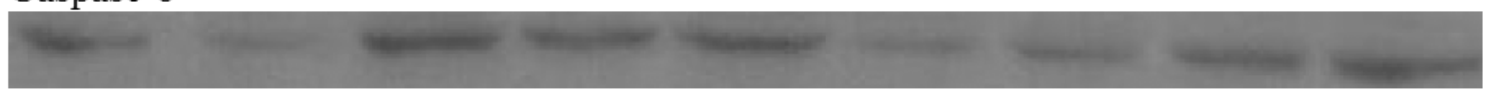

\section{Smac/Diablo}

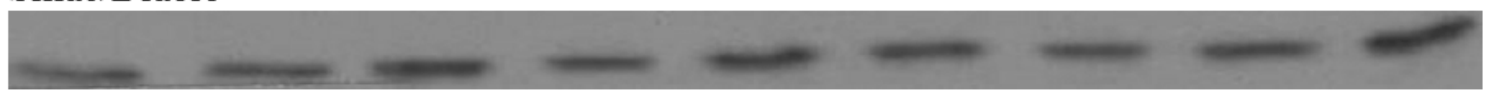

CDK-4

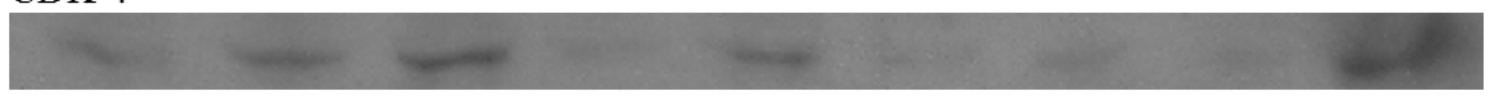

Bax

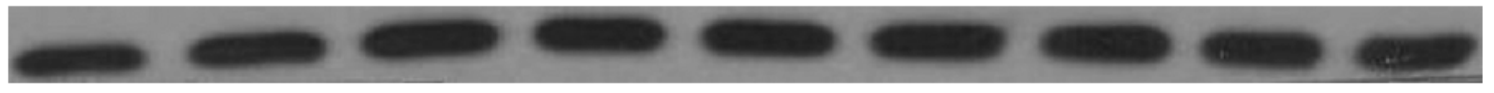

\section{Bcl-2}

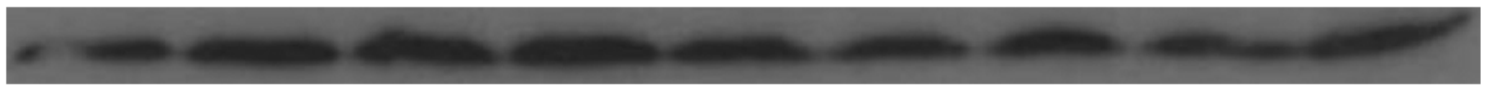

P53

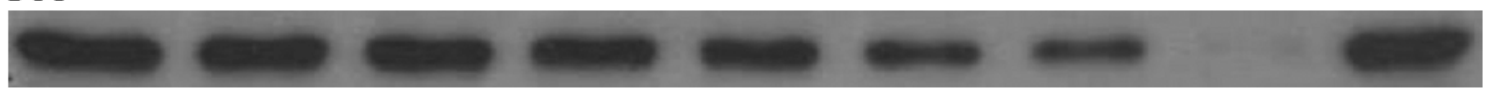

\section{Actin}

Figure 4. Western blot results for Jurkat cells treated with different concentrations of $P$. ostreatus extract

Lane 1: $1 \mathrm{mg} / \mathrm{ml}$, Lane 2: $2 \mathrm{mg} / \mathrm{ml}$, Lane 3: $4 \mathrm{mg} / \mathrm{ml}$, Lane 4: $5 \mathrm{mg} / \mathrm{ml}$, Lane 5: $8 \mathrm{mg} / \mathrm{ml}$, Lane 6: $10 \mathrm{mg} / \mathrm{ml}$, Lane 7: $16 \mathrm{mg} / \mathrm{ml}$, Lane $8: 20 \mathrm{mg} / \mathrm{ml}$, and Lane 9: the negative control which contains extracted proteins from untreated cells. 